\title{
KONSEP PENDIDIKAN ISLAM PERSPEKTIF H.O.S TJOKROAMINOTO
}

\author{
Arif Rahman Hakim
}

Prodi Pendidikan Agama Islam (PAI), STIT al Urwatul Wutsqo Jombang e-mail: ayipuyip@gmail.com

Wirano

Prodi Pendidikan Agama Islam (PAI), STIT al Urwatul Wutsqo Jombang

\begin{abstract}
The values of Islamic teachings brought by the great prophet Muhammad SAW, according to him, if we further explore and learn about them in Islam they will be implemented in life and nationality, and can also help face all the problems faced by the Indonesian people . In essence, the main idea of Islamic socialism according to the understanding of HOS Tjokrominoto is how to position and function religion (in this case Islam) as a revolutionary force to liberate oppressed people both culturally and politically and politically. HOS Tjokroaminoto is the son of a priyai who started the struggle against colonialism through the Sarekat organization Islam which is based on Islamic ideology and Socialism. HOS Tjokroaminoto's Islamic education perspective is very significant in a country. Education in question is education based on Islamic teachings, because in that teaching humans can find national values.
\end{abstract}

Keywords: Islamic Education, HOS Tjokroaminoto

\section{A. Pendahuluan}

Pendidikan bagi kehidupan umat manusia merupakan kebutuhan mutlak yang harus di penuhi sepanjang hayat. Tanpa pendidikan sama sekali mustahil suatu kelompok manusia dapat hidup berkembang sejalan dengan ispirasi (cita-cita) untuk maju, sejahtera dan bahagia menurut konsep pandangan hidup mereka. Semangkin tinggi cita-cita manusia semangkin menuntut kepada peningkatan mutu pendidikan sebagai sarana mencapai citacita tersebut. Akan tetapi di balik itu, karna semangkin tinggi cita-cita yang hendak di raih, maka semangkin kompleks jiwa manusia itu, karna didorong oleh tuntutan hidup (rising demands) yang meningkat pula. ${ }^{1}$

Realitas yang terjadi dalam kehidupan masyarakat selalu bersifat dinamis, semuanya selalu berubah-ubah. Perubahan sosial ini terjadi akibat

\footnotetext{
${ }^{1}$ Ihsan Fuad, Dasar-dasar Kependidikan, (Jakarta: Rineka Cipta, 2003)30.
} 
reaksi manusia dalam masyarakat terhadap gejala-gejala sosial khususnya fenomena politik, ekonomi dan budaya. Perubahan sosial yang dipicu oleh gejala politik misalnya penindasan yang dilakukan kekuatan penguasa dalam hal ini merupakan kekuatan imperialisme di indonesia terhadap rayat tertindas, telah menyebabkan terjadinyagelombang perlawanan dalam sejarah penjajahan imperialisme di indonesia. H.O.S Tjokrominoto dan Sarikat Islam tampil sebagai pelopor bangkitnya kesadaran di indonesia dalam melakukan perlawanan terhadap penindasan Imperialisme di Indonesia. H.O.S Tjokrominoto merupakan tokoh pergerakan nasional, ia adalah seorang penganjur Indonesia yang berkaliber besar, besar pekerjaan dan bangkitnya untuk tanah air dan agama Islam, dalam sosial dan politik. $^{2}$

Pendidikan Islam adalah bimbingan jasmani, rohani berdasarkan hukum-hukum agama Islam menuju kepada terbentuknya kepribadian utama menurut ukuran-ukuran Islam. Dengan pengertian yang lain sering kali beliau mengatakan keperibadian utama dengan istilah kepribadian muslim, yaitu kepribadan yang memiliki nilai-nilai agama Islam. ${ }^{3}$

Tantangan dan masalah-masalah internal pendidikan Islam pasca globalisasi pada hari ini dan masa depan, secara umum adalah sebagai berikut: Pertama, jenis pendidikan yang dipilih dan di laksanakan, dengan terjadinya perubahan kebijakan-kebijakan dan politik pendidikan. Kedua, persoalan identitas diri lembaga-lembaga Islam tertentu. Dan Ketiga, penguatan kelembagaan dan manajemen suatu lembaga pendidikan Islam ${ }^{4}$. Penerapan pendidikan islam yang berusaha untuk mengembangkan kepentingan Budipekerti luhur serta amal saleh, dengan menguasai ilmu pengetahuan dan keahlian teknologi yang fungsional bagi pembangunan bangsa dan Negara Republik Indonesia berdasarkan pancasila dan UUD 1945.

${ }^{2}$ Djaya Tamar, Pusaka Indonesia Riwayat Orang Orang Besar di Tanah Air, (Jakarta: Bulan Bintang,1999),166.

${ }^{3}$ Ahmad Tafsir, Ilmu Pendidikan dalam Perspektif Islam, (Bandung: Remaja Rosdakarya, 1992),5

${ }^{4}$ Marwan Saridjo, Mereka Bicara Pendidikan Islam: Sebuah Bunga Rampai, (Jakarta: Raja Grafindo, 2009),20 
Berbicara mengenai pendidikan di Indonesia, akan ditemukan berbagai fakta menarik dilapangan, mulai prestasi hingga problem-problem substansif yang terus bergulir dari masa kemasa. Langkah demi langkah telah dilakukan oleh para pemangku kekuasaan maupun pihak-pihak yang terkait, seperti pemikir, para pendidik, serta tokoh-tokoh besar demi menemukan suatu bentukpendidikan yang sesuai dengan atmosfer sosialdan budaya Negara ini. Pergantian tahun selalu diwarnai dengan bergantinya kurikulum baru serta berbagai sistem pendidikan yang digadang-gadangkan akan mampu menyelesaikan berbagai masalah diindonesia, yang diasumsikan berasal dari buruknya kualitas pendidikan dinegeri ini.

Salah satu tokoh yang lahir dari keadaan ini adalah seorang pejuang dan pemikir Islam yaitu H. O. S Tjokrominoto, beliau adalah seorang pejuang sejati yang sangat keras dalam memperjuangkan hak-hak masyarakat pribumi. Kecerdasan dan keberanian beliau inilah yang membuat ia ditakuti dan di segani oleh lawan-lawannya. Sebagai seseorang yang mempunyai intelektual yang mempuni, H. O. S Tjokrominoto mampu mengadopsi dan menerima gagasan-gagasan yang berkembang di luar Indonesia, pemikiranpemikiran para tokoh revolusioner di berbagai belahan dunia mampu diformulasikan kembali untuk mengatasi problematika-problematika yang di hadapi oleh bangsa Indonesia. Salah satu pikiran atau pemikiran yang di gagas oleh H. O.S Tjokrominoto adalah bagaimana mencoba menggali lagi nilai-nilai atau asas Islam untuk memberikan jalan keluar atau solusi terhadap permasalahan yang dihadapi bangsa Indonesia terutama permasalahan untuk membebaskan bangsa Indonesia terutama permasalahan untuk membebaskan bangsa Indonesia dari penjajahan.

Ia berpendapat bahwa nilai-nilai agama Islam yang di bawa oleh nabi besar Muhammad SAW harus kita gali dan kita tafsirkan kembali sehingga dapat diimplementasikan dalam kehidupan dan berkebangsaan. Sesungguhnya yang paling penting bagaimana ajaran Islam tersebut dapat dijadikan nilai dasar perjuangan untuk mengusir para penjajah dari bangsa tercinta ini. Menurut nilai-nilai Islam tersebut dapat diimplementasikan 
dalam kehidupan dan berkembangsaan. Sesungguhnya yang paling penting bagaimana ajaran Islam tersebut dapat dijadikan nilai dasar perjuangan untuk mengusir para penjajah dari bangsa yang tercinta ini. Menurut nilai-nilai islam tidak hanya mengatur hubungan antara manusia dengan Tuhan, akan tetapi lebih dari itu nilai-nilai tersebut juga banyak menyatakan dengan tegas bahwa Islam menginginkan keselamatan dan persatuan bagi seluruh manusia di muka bumi ini, Islam adalah agama perdamaian dan keselamatan.

Nilai-nilai ajaran Islam yang di bawa oleh nabi besar Muhammad SAW, menurut beliau, apabila lebih jauh kita gali dan kita pelajari dalam ajaran Islam tersebut akan dapat diimplementasikan dalam kehidupan dan berkebangsaan, dan dapat juga membantu menghadapi seluruh permasalahanpermasalahan yang dihadapi oleh bangsa Indonesia. Pada intinya pokok pemikiran sosialisme Islam menurut pengertian H.O.S. Tjokrominoto adalah bagaimana memposisikan dan memfungsikan agama (dalam hal ini Islam) sebagai sebuah kekuatan revolusioner untuk membebaskan rakyat yang tertindas baik secara kultural dan politik.

\section{B. Pembahasan}

\section{H.O.S. Tjokroaminoto Berjuang Melalui Sarekat Islam}

Sejak 1901, Belanda mulai menata politik kolonialnya dari kebijakan tanam paksa menjadi politik Etis, dengan dijembatani kebijakan liberal. Antara dua kebijakan itu, Politik Etis merupakan hasil kemenangan atas dijalankan tawaran kebijakan dua kelompok di parlemen Belanda, yaitu kelompok sosialis dan agama (1901-1942), setelah sebelumnya haluan kebijakan politik negeri Belanda dikuasai oleh Kelompok politik Konservatif (1817-1870) yang mencetuskan sistem cultuurstelsell tanam paksa pasca-kembalinya Belanda ke nusantara, menjadi politik Liberal (1870-1900) dengan sistem free Labour.

Tahun 1877, kurang lebih empat puluh tujuh tahun dijalankan politik cultuurstelsel bersamaan berakhirnya perang jawa dengan peristiwa penangkapan pangeran Dipenogoro. Perekonomian pemerintah kolonial Belanda stabil kembali tahun itu, Belanda mengantongi 
keuntungan mencapai 823 juta golden. Berakhirnya perang Jawa dan mulainya politik yang sebenarnya. Kebijakan cultuurstelsell berlanjut hingga tahun 1919. Perekonomian Belanda yang sempat hancur berantakan akibat kalah perang dari Perancis dan Inggris, serta banyak membendung perlawanan di berbagai daerah nusantara, mendapatkan darah baru dari kebijakan cultuurstelsell dan menjadi stabil kembali.

Antara tahun 1877 sampai dengan 1919 terjadi perubahan kebijakan politik etis biasa juga disebutkan politik utang budi. Akan tetapi, satu hal yang sama, yaitu bagaimana Belanda tetap melenggangkan kekuasaannya di tanah kolonial nusantara. Penulis melihat bahwa tiga kebijakan politik Belanda dalam mempertahankan kekuasaan tersebut tidak seperti potongan-potongan kebijakan yang berkembang sendiri-sendiri. Semuanya merupakan gagasan dan kebijakan by design yang tak mungkin lepas dari kepentingan. Seperti yang akan kita lihat nanti, pada era tahun 1901-1919, bukanlah era politik Etis. Era tersebut merupakan era paling runyam dalam sejarah kebijakan Belanda, Era Titik Chaos ${ }^{5}$. Pemikiran H.O.S. Tjokroaminoto mengandung nilai-nilai kebangsaan yang muaranya digunakan untuk melawan penindasan kolonial Belanda bersama para tokoh perjuangan yang lain. Nilai-nilai kebangsaan di tentukan melalui jalur pendidikan. Pendidikan merupakan salah satu kebutuhan hak asasi manusia bahkan manusia itu akan menjadi manusia pendidikan. Oleh karena itu maju mundurnya suatu kaum sangat bergantung sebagian besar kepada pendidkan yang berlaku dikalangan mereka. Oleh karena itu, perlu disusun pendidikan kebangsaan, sebab pendidikan kebangsaan akan selalu menjaga dan membina nilai-nilai patriotisme. Tujuan pendidikan kebangsaan yang ingin di capai menurut H.O.S Tjokroaminoto adalah untuk menjadikan anak didik sebagai

5 Mulawarman Aji Dedi, Jang Oetama Jejak Dan Perjuangan H.O.S. Tjokroaminoto ,(Yogyakarta: Galang Pustaka, 2016). 25 
seseorang muslim yang sejati dan sekaligus menjadi seorang nasionalis yang berjiwa besar penuh kepercayaan kepada diri-sendiri. ${ }^{6}$

Gerakan pemberontakan Islam yang di gagas oleh Tjokroaminoto identik dengan muncul dan perkembangannya sarekat Islam. Pada awal kemunculannya, masa paling signifikan adalah dua puluh tahun pertama sejak didirikan. Disebutkan bahwa masa dua puluh tahun awal ini merupakan masa pembentukan corak sarekat Islam. Kemudian pada masa-masa penghujung periode tersebut merupakan puncak sebuah organisasi bernama sarekat Islam berada di atas angin. Dinamika sarekat Islam setidaknya memperlihatkan pola naik-turunnya posisi dan peran umat Islam di Indonesia yang mendasarkan ideologinya pada ajaran Islam. Islam sebagai pemersatu. Harapan mereka bahwa sarekat Islam akan memecahkan semua probelum yang dihadapi. Tanggal 10 September 1912, H.O.S. Tjokroaminoto kemudian melakukan langkah taktis. Setelah selesainya draf perubahan anggaran sekaligus perubahan nama dari Sarekat Dagang Islam menjadi Sarekat Islam, SI didaftarkan pada notaris Belanda Mr. Dommering di Surabaya dengan taktik bahwa SI Surabaya bukan merupakan bagian dari SI Surakarta. Bila dilihat lebih jauh, anggaran dasar tersebut secara tegas dan formal menginginkan perubahan orientasi yang sangat kental, dari yang hanya berorientasi dengan menjadi lebih luas, menasional dan bahkan relegious Islam sebagai representasi mayoritas masyarakat Bumiputra. ${ }^{7}$

Sarekat Islam adalah satu diantara organisasi politik Indonesia abad ke-20 yang paling menonjol. Berbeda dengan Muhammadiyah yang bercorak Sosio-keagamaan, SI sejak semula adalah gerakan politik. SI adalah transformasi dari Sarekat Dagang Silam (SDI), didirikan pada 11 november 1911, oleh H. Samanhudi, seorang pedagang muslim kaya dari Surakarta, Jawa Tengah. SDI mula-mula diarahkan melawan kegiatan

${ }^{6}$ Aminudin dkk, Pendidikan Agama Islam untuk Perguruan Tinggi, (Jakarta: Ghalia Indonesia, 2002) 50.

${ }^{7}$ Mulawarman Aji Dedi, Jang Oetama Jejak Dan Perjuangan H.O.S. Tjokroaminoto ,(Yogyakarta: Galang Pustaka, 2016). 25 
China yang menguasai dunia perdagangan dengan mengorbankan pribumi. Sisi lain dari perlawanan itu, sekalipun tidak langsung, ditujukan kepada belanda yang memberikan prioritas dan perlindungan kepada usahawan China yang agresif dalam perdagangan dan industri. Pada 1912 SDI menjadi SI, dan mendapatkan pemimpin organisator baru yang kompeten, H.O.S. Tjokroaminoto. Perubahan SDI menjadi SI bukan hanya dalam perubahan nama, tapi terutama dalam perubahan orientasi, yaitu dari komersial ke politik.

Sebelum membicarakan reaksi SI terhadap ideologi-ideologi modern ini, sebuah catatan singkat tentang Marxisme di Indonesia perlu disertakan. Marxisme atau kemudian lebih dikenal dalam baju Komunisme pertama kali diperkenalkan oleh tokoh-tokoh Marxis Belanda, yang diketahui oleh H.J.F. Sneevliet. Pada tahun 1914 Kelompok Marxis mendirikan ISDV (Indische Sociaal Democratische Vereeniging, Organisasi Social Demokrat Hindia Belanda), dan lewat Organisasi inilah kemudian gagasan-gagasan dan slogan-slogan Marxis 'diekspor' kedalam tubuh SI. Pemimpin-pemimpin pergerakan Islam pada waktu itu nampaknya belum begitu siap untuk suatu perjuangan ideologi bila dihadapkan kepada ideologi Marxis yang agresif ${ }^{8}$.

\section{Tokoh Guru Besar dan Pemikirannya}

Begitu nampak dalam perjalanan hidupnya bahwa Islam dipeluknya sebagai pedoman utama dalam berucap dan bertindak. Hal inipun diajarkannya pada anak dan pengikutnya bahwa hanya Islamlah yang dapat membawa kebahagiaan umat dan umat untuk menjadi seorang muslim yang seutuhnya maka harus dididik secara islami. Tempo menjelaskan bahwa pada tahun 1930-an banyak berdiri sekolah Tjokroaminoto yang dibangun cabang-cabang PSII di semua wilayah. Silabus dan kurikulumnya didasari oleh buku Tjokro yakni Moeslim Nationaal Onderwijs. Sekolah ini mengajarkan soal arti kemerdekaan, budi pekerti, ilmu umum, dan ilmu

${ }^{8}$ Ahmad Syafi'I Maarif, Islam dan Masalah Kenegaraan, (Jakarta: LP3ES, 1985), 60 
keislaman. Menurutnya asas-asas Islam sejalan dengan sosialisme dan demokrasi maka kaum muslimin harus dididik menjadi muslim sejati untuk mencapai cita-cita kemerdekaan umat.

Setidaknya terdapat 5 pemikiran utama Tjokroaminoto dalam mendidik umatnya yang semuanya berlandaskan pada nafas islami. Tjokroaminoto bukan hanya mengajarkan gagasannya secara lisan tetapi juga memperlihatkannya dalam kehidupannya (perilakunya). Inilah yang membuat anak kandung serta anak kosnya begitu kagum padanya. Sesuatu yang paling sulit dilakukan adalah menyamakan antara ucapan dan perilaku, memang manusia tiada yang sempurna tetapi Tjokroaminoto berusaha untuk mencapainya.

a. Gagasan pertamanya adalah menanamkan benih kemerdekaan dan benih demokrasi yang telah menjadi tanda kebesaran dan tanda perbedaan Umat Islam besar pada zaman dahulu. Tjokroaminoto memberikan pelajaran baik pada anaknya dan anak kosnya tentang arti kemerdekaan dan demokrasi yakni membela kebenaran dan berpihak pada rakyat serta hanya takut pada Allah SWT. Suatu ketika pernah anaknya yang baru lulus sekolah memberikan ijazah kelulusannya pada sang ayah tetapi bukan bangga atau senang, Tjokroaminoto kemudian dengan tegas malah merobeknya berkali-kali dan menegaskan pada anaknya bahwa lebih baik untuk menjadi abdi rakyat dengan membangun cabang SI. Anak kos Tjokroaminotopun pernah merasakan arti demokrasi yakni ketika Tjokroaminoto sedang berdiskusi dengan teman-temannya, mereka sering berbeda pendapat dalam memutuskan sesuatu sehingga kemudian diambil jalan tengahnya. Para anak kosnya ini biasanya hanya duduk mendengarkan dan mengamati saja. Tjokroaminoto memahami pentingnya rapat umum dan keberanian bicara buat menggalang massa. Di meja makan rumah Gang Peneleh, ilmu pergerakan modern ditularkan pada Alimin, Moeso, Sukarno, dan Kartosoewirjo.

b. Buah pikirannya yang kedua dengan menanamkan benih keberanian yang luhur, benih keikhlasan hati, kesetiaan dan kecintaan kepada yang benar 
(haq), yang telah menjadi tiap tabiat masyarakat Islam pada zaman dahulu. Tempo dengan gamblang memberi penjelasan bahwa Tjokroaminoto pernah akan dibunuh mertuanya dan rela meninggalkan pekerjaan serta gelar ningratnya karena ia merasa mertuanya ini begitu menghamba pada penjajah dan pikirannya sangat kolot. Nasib bangsa begitu buruk hal ini tidak kurang diakibatkan karena peran penjajah yang menyedot ribuan gulden setiap tahunnya. Maka tak salah jika kemudian sebutan mesiah dari tanah jawa atau Heru-Tjokro disematkan padanya.

c. Hasil gagasannya yang ketiga dan keempat ialah menanamkan benih peri kebatinan yang halus, keutamaan budi pekerti dan kebaikan perangai, dan kehidupan yang saleh, yang dulu telah menyebabkan orang Arab penduduk laut pasir itu menjadi bangsa tuan yang halus adat lembaganya dan menjadi penanam dan penyebar keadaban dan kesopanan. Tjokroaminoto dengan segala tulisannya menggambarkan bagaimana seseorang harus berperilaku setidaknya setiap muslim harus menjadi muslim yang seutuhnya yang merasuk hingga rasa dan jiwanya. Hal ini tergambar jelas pada silabus dan kurikulum yang terjabarkan pada sekolah Tjokroaminoto disetiap cabang SI.

d. Gagasannya yang terakhir ialah menanamkan rasa kecintaan terhadap tanah tumpah darah dengan jalan mempelajari kultur dan adat istiadat bangsa sendiri. Tjokroaminoto seringkali dalam satu atau dua minggu sekali mengadakan latihan wayang orang bertempat tempat seni Panti Harsoyo bersama anak-anaknya \& anak-anak pondokannya. Tjokro gemar bermain gamelan dan menari dan Istrinya suka bermain piano, hal ini menular pada anaknya. Salah seorang anaknya Harsono bukan hanya meneladani kegemaran orang tuanya tersebut tetapi meneladani semangat patriotisme, cinta tanah air, dan sifat kesederhanaan, dan gemar membantu sesamanya. Harsono menyaksikan dengan mata kepala sendiri, meskipun orang tuanya menempati gedung yang luas namun sebagian dari ruangannya disediakan untuk menampung anak muda pelajar sedangkan kehidupan sendiri sehari-hari selalu tidak pernah 
berlebih-lebihan, serba apa adanya. Harsono sering diajak dalam perjalanan ke desa-desa untuk menghadiri pertemuan-pertemuan Sarekat Islam. Awalnya Harsono tidak mengerti apa yang dilakukan ayahnya tetapi lama kelamaan ia mengerti apa yang dilakukan ayahnya tersebut dan secara otomatis tidak terasa timbul pula rasa kesadaran dalam batinnya; kesadaran cinta tanah air, kesadaran sebagai seorang muslim, kesadaran mengabdikan diri pada negara dan bangsa. Kesadaran untuk berkorban pada agama yang diyakini. Kesan terdalam Harsono pada ayahnya ketika ayahnya dalam memberikan nasihat pada anak-anaknya tidak menggunakan kata-kata tetapi lebih diutamakan pada contoh serta perbuatan yang baik.

Selain itu bagi Tjokroaminoto pendidikan Islam dilakukan pertama kali dengan mengaji untuk mendalami agama Islam, bukan hanya sekedar membaca disertai ilmu tajwidnya tetapi juga memaknai setiap ayat dalam kehidupan sehari-hari. Tjokroaminoto juga seringkali mengawasi kemajuan putra-putrinya dalam mengaji dan menunggu mereka hingga selesai mengaji.

\section{Menegakkan Negeri Melalui Sosialisme Islam}

Sosialisme Islam sebagai sumber nilai organisasi Sarekat Islam digagas oleh Tjokro usai terjadinya perpecahan diinternal organisasi. Hal tersebut dikarenakan menguatnya rongrongan kalangan komunis dan tekanan bertubi-tubi dari Belanda. Sebelum menelusuri lebih lanjut gagasan utama dan substansi Sosialisme Islam, peneliti ingin menjelaskan latar belakang munculnya ide Tjokroaminoto mengenai Sosialisme Islam. Dari beberapa peristiwa penting disekitar munculnya ide Sosialisme Islam, yang terpenting adalah September 1922. Ketika itu, Tjokroaminoto menerbitkan tulisan berseri berjudul "Islam dan Sosialisme" di Soeara Boemipoetra. Tulisan ini sangat dimungkinkan muncul saat Tjokroaminoto berada di penjara, sejak Agustus 1921 sampai dengan April 1922. Peristiwa penting lain adalah inisiatif Tjokroaminoto bersama Agoes Salim sebagai wakil Sarekat Islam mengundang berbagai organisasi pergerakan berideologi 
Islam dalam pembentukan Kongres Al-Islam 31 Oktober - 2 November 1922 di Cirebon. Dalam kongres Al- Islam, Tjokroaminoto meluncurkan ide Sosialisme Islam dan program tandhim. Rancangan pemikiran Tjokroaminoto mengenai Sosialisme Islam sebagai ideologi pergerakan, akhirnya nanti, ditetapkan pada Kongres Nasional Sentral Sarekat Islam ketujuh, tanggal 17-23 Februari 1923 di Madiun. Penetapan itu juga mengubah Sarekat Islam menjadi Partai Sarekat Islam Indonesia. ${ }^{9}$

\section{Usaha Tanpa Lelah Rekatkan Negeri}

Sekitar April 1922, Tjokroaminoto menghirup udara kebebasan keluar dari penjara. Bu Roestina menjemput pembebasan Tkoroaminoto. Sesampainya di Surabaya, Tjokroaminoto disambut meriah oleh keluarga, anak-anak, dan anggota SI. Meriahnya sambutan Tjokroaminoto terutama ketika dilakukan pertemuan dengan anggota SI dirumah pengurus SI Surabaya, Mansoer, di daerah Bubutan, Surabaya. Hampir seluruh pengurus hadir. Salah satu yang hadir di forum itu adalah sahabat karib Tjokroaminoto, Wondoamiseno. Kehadiran Pak Tjokroaminoto dalam pertemuan itu seakan memberikan suntikan energi bagi anggota yang mulai kendor.

Sejak disiplin partai, cabang-cabang SI banyak dirongrong kelompok komunis, tak terkecuali SI Surabaya yang juga di rundung masalah serius. Karena rumitnya permasalahan tersebut, Wondoamiseno memintanya hadir untuk mendiskusikannya. Pengurus SI menyampaikan bahwa rongrongan kaum komunis sudah sampai di Surabaya. Semaoen masih melakukan rongrongan, dan memunculkan Sarekat Rakyat. Beberapa daerah mendirikan Sarekat Islam Merah sebagai tandingan Sarekat Islam pimpinan Pak Tjokro. Tak terkecuali di Surabaya, gerakan SI merah telah merambah pula di kalangan anggota. Ketua cabang SI Surabaya, Soekiran, pindah ke luar kota dan menyatakan tidak mau lagi menduduki jabatan ketua. Kondisi tersebut dimanfaatkan kader Semaoen dan kawan-kawan di

${ }^{9}$ Mulawarman Aji Dedi, Jang Oetama Jejak Dan Perjuangan H.O.S. Tjokroaminoto ,(Yogyakarta: Galang Pustaka, 2016). 28 
Surabaya, simoen Bd., dengan membentuk committee Boedi Kamuljaan (CBK). Tujuannya adalah sebagai jalan masuk membentuk SI Merah. Perseteruan makin memanas, apalagi saling klaim antara CBK dan pengurus SI Surabaya, siapa pemegang amanah SI Surabaya muncul ke permukaan lewat media Oetoesan Hindia.

\section{Pengertian Pendidikan Islam}

Menurut bahasa, pendidikan berasal dari kata Education yang dapat diartikan upbringing (Pengembangan), teaching (Pengajaran), instruction (Perintah), pedagogy (Pembinaan kepribadian), breeding (Memberi makan), raising (of animal) (Menumbuhkan). Dalam bahasa Arab, kata pendidikan merupakan terjemahan dari kata al-tarbiyah yang dapat diartikan proses menumbuhkan dan mengembangkan potensi yang terdapat pada diri seseorang, baik secara fisik, psikis, sosial, maupun spiritual. ${ }^{10}$

Selanjutnya kita perhatikan Islam, sering dikatakan bahwa Islam adalah sebuah agama yang berorientasi pada Muhammad, Nabi dari Arab pada abad ke-7. Islam adalah kepatuhan atau penyerahan diri, yaitu dalam mengenali kedaulatan Allah dan memasuki rasa kedamaian milik-Nya. Islam pada mulanya telah menunjukkan pada perbuatan pribadi atau sikap pikiran daripada sebuah sistem keagamaan (Robinson, 2001: 22).

Secara harfiah, Islam berasal dari bahasa Arab, salima, yang antara lain berarti to be safe (terpelihara) and sound (dan terjaga), unhermend (tidak celaka), intact, safe (terjaga), secure (terjaga), to be unobjectionable, belameless, faultless, to be certain, established (terbentuk), to escape (terjaga), turn over (melewati), dan surrender (pengabdian). Dari kata salima yang merupakan tsulatsi mujarrad, kata yang berakar pada tiga huruf, menjadi aslama yang merupakan tsulatsi majid, kata yang mendapatkan tambahan satu huruf.

${ }^{10}$ Abuddin Nata, Sejarah Pendidikan Islam, (Jakarta: Kencana, 2011),15. 
Jadi, pendidikan Islam adalah pendidikan iman dan amal. Karena ajaran Islam berisi ajaran tentang sikap dan tingkah laku pribadi masyarakat, menuju kesejahteraan hidup perorangan dan bersama, maka pendidikan Islam adalah pendidikan individu dan masyarakat. ${ }^{11}$

\section{Konsep Pendidikan Islam}

Pendidikan Islam sebagai proses intraksi sosial yang melibatkan berbagai faktor pendidikan dalam upaya untuk membentuk perubahan yang diinginkan pada hakikatnya dapat dianggap sebagai inti dari dakwah Islam itu sendiri. ${ }^{12}$

Pendidikan dalam pengertian luas adalah meliputi semua perbuatan atau usaha untuk melimpahkan pengetahuannya, pengalamannya, kecakapan serta ketrampilannya kepada generasi muda sebagai usaha untuk menyiapkan mereka dalam memenuhi fungsi hidupnya baik jasmaniah maupun rokhaniah.

Pendidikan Islam adalah pendidikan yang lebih banyak ditujukan perbaikan sikap mental, yang nanti akan teruwud dalam amal perbuatan, selain pendidikan Islam juga tidak memisahkan antara Iman dan amal sholeh, sehingga dapat dikatakan bahwa pendidikan Islam mencakup amal dan pendidikan iman. ${ }^{13}$

Dengan kata lain misi pendidikan sebagai usaha menubuhkan daya kreatifitas anak didik dengan kemampuan yang produktif. Karena itu, Islam mengajarkan agar mendidik anak haruslah semaksimal mungkin. Artinya orang tua atau pendidik jangan sampai meninggalkan anak-anak yang lemah baik fisik maupun psikis. al-Qur'an berpesan bahwa jangan sampai pendidikan anak diabaikan dan terbengkalai (QS. An-Nisa: 9). Anak harus dididik menjadi generasi yang matang dan sempurna. Adapun proses pematangan potensi anak adalah dengan pendidikan. Quraisy Shihab mengatakan bahwa kata "tarbiyah" seakar dengan kata "rabb" yaitu mengarahkan sesuatu tahap demi tahap menuju kesempurnaan kejadian dan

${ }^{11}$ Daradjat, Zakiah. Ilmu Pendidikan Islam, (Jakarta: Bumi Aksara, 2014),28

${ }^{12}$ Abu Ahmadi dan Nur Uhbuyati, IlmuPendidikan, (Jakarta: RinekaCipta, 1997)

${ }^{13}$ Daradjat, Zakiah. Ilmu Pendidikan Islam, (Jakarta: Bumi Aksara, 2014),30 
fungsinya. Selanjutnya, pengertian "rububiyah" (kependidikan atau pemeliharaan) Allah menyangkut pemberian rizki, pengampunan dan kasih sayang, amarah, ancaman, dan siksaan-Nya. Maka ini akan terasa dekat ke benak kita saat mengancam, bahkan memukul anak kita dala rangka mendidik mereka. Walaupun sang anak yang dipukul merasa diperlakukan tidak wajar, kelak setelah dewasa ia akan sadar bahwa pukulan tersebut merupakan sesuatu yang baik baginya. ${ }^{14}$

\section{Dasar Pendidikan Islam}

Dasar adalah pangkal tolak suatu aktivitas. Di dalam menetapkan dasar suatu aktivitas manusia selalu berpedoman kepada pandangan hidup dan hukum-hukum dasar yang di anutnya, karna hal ini yang akan menjadi pegangan dasar didalam kehidupannya. Apabila pandangan hidup dan hukum dasar yang dianut manusia berbeda, maka berbeda pulalah dasar dan tujuan aktivitasnya.

Dasar pendidikan Islam tentu saja didasarkan kepada falsafah hidup umat islam dan tidak didasarkan kepada falsafah hidup, suatu Negara sebab sistem pendidikan Islam tersebut dapat dilaksanakan dimana saja dan kapan saja tanpa di batasi ruang dan waktu. ${ }^{15}$

Abdul Wahab Khallaf mendefinisikan al-Qur'an sebagai berikut, Kalam allah yang diturunkan melalui Malaikat Jibril kepada hati Muhammad Rasulullah SAW anak Abdullah dengan lafaz Bahasa Arab dan makna hakiki untuk menjadi hujjah bagi Rasulullah atas kerasulannya dan menjadi pedoman bagi manusia dengan petunjuk beribadah membacanya.

Nabi Muhammad SAW sebagai pendidik pertama, pada masa awal pertumbuhan Islam telah menjadikan al-Qur'an sebagai dasar pendidikan Islam di samping sunnah beliau sendiri.

Kedudukan, al-Qur'an sebagai sumber pokok pendidikan Islam dapat dipahami dari ayat al-Qur'an itu sendiri.

Firman Allah:

${ }^{14}$ Quraish Shihab, Pesan, Kesandan Keserasian al-Qur'an Vol. 1, (Jakarta: lentera Hati, 2002),20

${ }^{15}$ Ramayulis, Ilmu Pendidikan Islam, (Jakarta: Kalam Mulia), 30 


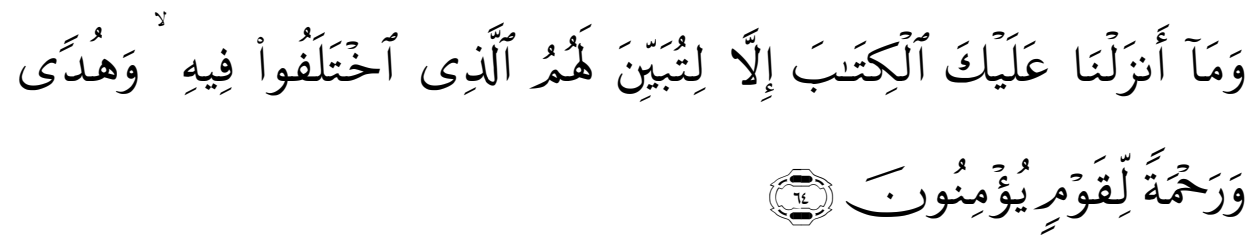

Artinya:" Dan kami tidak menurunkan kepadamu al-Kitab (alQur'an) ini melainkan agar kamu dapat menjelaskan kepada mereka perselisihan itu dan menjadi petunjuk dan rahmat bagi kaum yang beriman."

Adapun maksud dari ayat tersebut adalah Allah SWT tidak menurunkan al-qur'an kepadamu (wahai Rasul), kecuali supaya kamu menerangkan kepada manusia perkara agama dan hukum-hukum yang mereka perselisihkan, sehingga hujjah agak tegak dihadapan mereka melalui penjelasanmu, yang tidak meninggalkan satu jalanpun bagi kebatilan untuk merasuk kedalam jiwa. Dan juga karena al-qur'an adalah hidayah yang tidak meninggalkan satu celahpun untuk bimbang, serta sebagai rahmat bagi kaum mukminin dalam sikap mereka mengikuti petunjuk dan menjauhi kesesatan.

Selanjutnya firman Allah SWT:

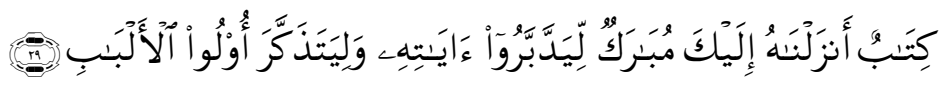

Artinya: "Ini adalah sebuah kitab yang kami turunkan kepadamu penuh dengan berkah supaya mereka memperlihatkan ayat-ayat-Nya. dan supaya mendapat pelajaran orang-orang yang mempunyai pikiran”. (Q. S. Shad: 29).

Maksud dari ayat tersebut adalah Sesungguhnya Al-Qur'an ini yang kami turunkan kepadamu wahai Nabi berisi banyak manfaat dan kebaikan, supaya Manusia merenungkan ayat-ayatnya dan memikirkan makna-maknanya, dan supaya orang-orang yang memiliki akal sehat dan cerdas mengambil pelajaran darinya.

\section{Tujuan Pendidikan Islam}

Istilah "tujuan" atau "sasaran" atau "maksud", dalam bahasa arab dinyatakan dengan ghayat atau ahdaf atau maqasid. sedangkan dalam bahasa Inggris, istilah "tujuan" dinyatakan dengan "goal atau purpose atau 
objective atau aim. Secara umum istilah-istilah itu mengandung pengertian yang sama, yaitu arah suatu perbuatan atau yang hendak dicapai melalui upaya atau aktivitas.

Pendidikan Sebagai proses alih nilai, secara makro memiliki tiga sasaran. Pertama, bahwa tujuan pendidikan untuk membentuk manusia yang mempunyai keseimbangan antara kemampuan kognitif dan psikosokomotor disatu pihak serta kemamuan efektif di pihak lain, dalam konteks keindonesiaan, hal yang dapat di artikan bahwa pendidikan menghasilkan manusia yg berkeperibadian yang tetap menjunjung tinggi nilai-nilai budaya yang luhur, serta mempunyai wawasan, sikap kebangsaan dan serta menumpuk jati diri, kedua dalam sistem sistem nilainilai keimanan, ketakwaan, dan ahlak yang mulia yang senantiasa menjaga harmonis hubungan dengan tuhan, dengan sesama manusia dan alam sekitarnya. Ketiga dalam alih nilai-nilai juga dapat transformasi tata nilai yang mendukung proses industrialisasi dan penerapan teknologi, seperti, disiplin, etos kerja, kemandirian, dan sebagainya. Tujuan yang akan dicapai adalah membentuk manusia yang beriman, bertaqwa, berakhlak mulia, maju dan mandiri sehingga memiliki ketahanan rohaniah yang tinggi serta mampu beradaptasi dengan dinamika perkembangan masyrakat. $^{16}$

\section{Analisis}

\section{Jejak dan Perjuangan H.O.S. Tjokroaminoto}

H.O.S. Tjokroaminoto adalah seorang pahlawan yang lahir di tengahtengah pergerakan belanda yang sedang mengatur arus politiknya. Kesadaran terhadap adanya penindasan dan penjajahan yang diberlakukan kepada pribumi, membuat Tkjokroaminoto berinisiatif membangun pendidikan agar manusia dapat mengetahui hakikat keberadaan dirinya. Melalui pendidikan, Tjokroaminoto dapat lebih mudah membangun karakter manusia yang pada hakikatnya memiliki hak dalam bernegara.

${ }^{16}$ Quraish shihab, Pesan, Kesandan Keserasian al-Qur'an Vol. 1, (Jakarta: lentera Hati, 2002),20 
Hal tersebut sesuai dengan yang dikutip Mawani bahwa, gerakan pemberontakan Islam yang di gagas oleh Tjokroaminoto identik dengan muncul dan perkembangannya sarekat Islam. Pada awal kemunculannya, masa paling signifikan adalah dua puluh tahun pertama sejak didirikan. Disebutkan bahwa masa dua puluh tahun awal ini merupakan masa pembentukan corak sarekat Islam. Kemudian pada masa-masa penghujung periode tersebut merupakan puncak sebuah organisasi bernama sarikat Islam berada di atas angin. Dinamika sarekat Islam setidaknya memperlihatkan pola naik-turunnya posisi dan peran umat Islam di Indonesia yang mendasarkan ideologinya pada ajaran Islam. Islam sebagai pemersatu. Harapan mereka bahwa sarekat Islam akan memecahkan semua problem yang dihadapi.

Setelah H.O.S. Tjokroaminoto membentuk organisasi Sarekat Islam, kemudian ia melanjutkan dengan perenanaan berikutnya. Seperti yang diungkapkan oleh mulawarman, pada tanggal 10 September 1912, H.O.S. Tjokroaminoto kemudian melakukan langkah taktis. Setelah selesainya draf perubahan anggaran sekaligus perubahan nama dari Sarekat Dagang Islam menjadi Sarekat Islam, SI didaftarkan pada notaries Belanda Mr. Dommering di Surabaya dengan taktik bahwa SI Surabaya bukan merupakan bagian dari SI Surakarta. Bila dilihat lebih jauh, anggaran dasar tersebut secara tegas dan formal menginginkan perubahan orientasi yang sangat kental, dari yang hanya berorientasi dengan menjadi lebih luas, menasional dan bahkan relegious Islam sebagai representasi mayoritas masyarakat Bumiputra. ${ }^{17}$

Sarekat Islam adalah satu diantara organisasi politik Indonesia abad ke-20 yang paling menonjol. Berbeda dengan Muhammadiyah yang bercorak Sosio-keagamaan, SI sejak semula adalah gerakan politik. SI adalah transformasi dari Sarekat Dagang Silam (SDI), didirikan pada 11 november 1911, oleh H. Samanhudi, seorang pedagang muslim kaya dari

17 Mulawarman Aji Dedi, Jang Oetama Jejak Dan Perjuangan H.O.S. Tjokroaminoto ,(Yogyakarta: Galang Pustaka, 2016).20. 
Surakarta, Jawa Tengah. SDI mula-mula diarahkan melawan kegiatan China yang menguasai dunia perdagangan dengan mengorbanka pribumi. Sisi lain dari perlawanan itu, sekalipun tidak langsung, ditujukan kepada belanda yang memberikan prioritas dan perlindungan kepada usahawan China yang agresif dalam perdagangan dan industri. Pada 1912 SDI menjadi SI, dan mendapatkan pemimpin organisator baru yang kompeten, H.O.S. Tjokroaminoto ${ }^{18}$. Perubahan SDI menjadi SI bukan hanya dalam perubahan nama, tapi terutama dalam perubahan orientasi, yaitu dari komersial ke politik.

Sebelum membicarakan reaksi SI terhadap ideologi-ideologi modern ini, sebuah catatan singkat tentang Marxisme di Indonesia perlu disertakan. Marxisme atau kemudian lebih dikenal dalam baju Komunisme pertama kali diperkenalkan oleh tokoh-tokoh Marxis Belanda, yang diketahui oleh H.J.F. Sneevliet. Pada tahun 1914 Kelompok Marxis mendirikan ISDV (Indische Sociaal Democratische Vereeniging, Organisasi Social Demokrat Hindia Belanda), dan lewat Organisasi inilah kemudian gagasan-gagasan dan slogan-slogan Marxis 'diekspor" kedalam tubuh SI. Pemimpin-pemimpin pergerakan Islam pada waktu itu nampaknya belum begitu siap untuk suatu perjuangan ideologi bila dihadapkan kepada ideologi Marxis yang agresif ${ }^{19}$.

\section{Konsep Pendidikan Islam Perspektif H.O.S. Tjokroaminoto}

Mengenai pendidikan H.O.S. Tjokroaminoto berpendapat bahwa, istilah tersebut sangat penting untuk dikembangkan dan diterapkan dalam segala situasi. Ia memandang pendidikan merupakan hal yang memberi peran positif terhadap kemajuan sebuah Negara, karena dengan pendidikan bisa diukur maju dan mundurnya sebuah Negara.

Hal ini sesuai dengan apa yang diungkapkan oleh Natsir, bahwa Pemikiran H.O.S Tjokroaminoto mengandung nilai-nilai kebangsaan yang muaranya digunakan untuk melawan penindasan kolonial Belanda

${ }^{18}$ Maarif, Syafi'I, Ahmad. Islam dan Masalah Kenegaraan, (Jakarta: LP3ES, 1985).97

${ }^{19}$ Maarif, Syafi'I, Ahmad. Islam dan Masalah Kenegaraan, (Jakarta: LP3ES, 1985).86 
bersama para tokoh perjuangan yang lain. Nilai-nilai kebangsaan di tentukan melalui jalur pendidikan. Pendidikan merupakan salah satu kebutuhan hak asasi manusia bahkan manusia itu akan menjadi manusia pendidikan. Oleh karena itu maju mundurnya suatu kaum sangat bergantung sebagian besar kepada pendidikan yang berlaku dikalangan mereka.

Amin juga menegaskan demikian bahwa, pendidikan kebangsaan akan selalu menjaga dan membina nilai-nilai patriotisme. Tujuan pendidikan kebangsaan yang ingin di capai menurut H.O.S Tjokroaminoto adalah untuk menjadikan anak didik sebagai seseorang muslim yang sejati dan sekaligus menjadi seorang nasionalis yang berjiwa besar penuh kepercayaan kepada diri-sendiri ${ }^{20}$

Sebagaimana dikatakan juga bahwa, satu pernyataan Tjokroaminoto yang cukup terkenal adalah, "Negara dan bangsa kita tidak akan mencapai kehidupan yang adil dan makmur. Pergaulan hidup yang aman dan tentram selama ajaran-ajaran Islam belum dapat berlaku atau dilakukan menjadi hukum dalam Negara kita, sekalipun sudah merdeka." Di sini Tjokroaminoto berpikir jauh ke depan ketika sebuah bangsa masih mencari jati dirinya.

\section{Penutup}

H.O.S. Tjokroaminoto adalah anak seorang priyai yang memulai perjuangan melawan penjajahan melalui organisasi Sarekat Islam yang berlandaskan pada ideologi Islam dan Sosialisme. Pendidikan Islam perspektif H.O.S. Tjokroaminoto adalah hal yang sangat signifikan sekali dalam sebuah Negara. Pendidikan yang dimaksud adalah pendidikan yang berlandaskan ajaran Islam, karena dalam ajaran itulah manusia dapat menemukan nilai-nilai kebangsaan.

20 Mulawarman Aji Dedi, Jang Oetama Jejak Dan Perjuangan H.O.S. Tjokroaminoto ,(Yogyakarta: Galang Pustaka, 2016),50 


\section{BIBLIOGRAPHY}

Ihsan Fuad, Dasar-dasar Kependidikan, Jakarta: Rineka Cipta, 2003.

Djaya Tamar, Pusaka Indonesia Riwayat Orang Orang Besar di Tanah Air, Jakarta: Bulan Bintang,1999.

Tafsir, Ahmad, Ilmu Pendidikan dalam Perspektif Islam, Bandung: Remaja Rosdakarya, 1992.

Saridjo, Marwan, Mereka Bicara Pendidikan Islam: Sebuah Bunga Rampai, Jakarta: Raja Grafindo, 2009.

Mulawarman Aji Dedi, Jang Oetama Jejak Dan Perjuangan H.O.S. Tjokroaminoto, Yogyakarta: Galang Pustaka, 2016.

Aminudin dkk, Pendidikan Agama Islam untuk Perguruan Tinggi, Jakarta: Ghalia Indonesia, 2002.

Syafi'I Maarif, Ahmad, Islam dan Masalah Kenegaraan, Jakarta: LP3ES, 1985.

Nata, Abuddin, Sejarah Pendidikan Islam, Jakarta: Kencana, 2011.

Abu Ahmadi dan Nur Uhbuyati, IlmuPendidikan, Jakarta: RinekaCipta, 1997

Daradjat, Zakiah. Ilmu Pendidikan Islam, Jakarta: Bumi Aksara, 2014.

Quraish Shihab, Pesan, Kesandan Keserasian al-Qur'an Vol. 1, Jakarta: lentera Hati, 2002.

Ramayulis, Ilmu Pendidikan Islam, Jakarta: Kalam Mulia. 